\title{
PREF ĀCE
}

There are values expressed at the formation of the United States and upheld in the greater moments of its history that affirm the necessary respect for the worth and dignity of man as a means of regulating society. These values include ideas of justice, equality, and freedom of choice, each defended as an inviolable human right. The men who created the United States assumed that the protection of these values was a reasonable and effective way of defining a nation's functions. There is, however, something disconcerting about dealing with U.S. foreign policy and these espoused values at the same time. U.S. policies seem structured to benefit the United States politically, economically, and militarily with little apparent regard for the impact these efforts have on the integrity of other nations' institutions. In this setting, the rights claimed in the Declaration of Independence sound increasingly like principles that apply only to the United States and its citizens often at the expense of those very rights for other peoples.

In Brazil in the early sixties, the erratic policies of the government of President João Goulart exacerbated the political unrest and economic troubles of the country. The U.S. response amplified Brazil's difficulties by lending support to national elements opposing the Goulart administration. U.S. actions ranged from political and economic sanctions and manipulations to military support for ridding Brazil of its president. That coup effected the replacement of Brazil's incomplete democracy with authoritarian military rule. Ambassador Lincoln Gordon and other U.S. officials suggested that Goulart's ouster had saved democracy in Brazil by confronting growing subversive elements in the government and society and by 


\section{xii Preface}

preventing Goulart's executing his own coup from the left in order to gain dictatorial powers. ${ }^{1}$

I believe that decisions by U.S. law and policy makers that affirm the value of the individual and respect his integrity are in the best interest of the United States and that if the United States is to have allies that respect both themselves and the United States it must approach these nations with a firm regard for the integrity of their institutions as well as for these principles. In my judgement, U.S. policy toward Brazil in the early sixties failed to take these values into sufficient account and thus contributed to yet another failure of institutions designed to safeguard individual freedoms and rights. My purpose in writing this book, however, is of narrower scope. It is simply to relate the story of U.S. activities in Brazil in the early sixties and what some of the more important actors said at the time and later remembered about these events.

This study draws heavily upon documents declassified in the Lyndon Baines Johnson ${ }^{2}$ and John F. Kennedy presidential libraries. I should note, however, that only the declassified portions of those documents that made their way to the White House files have been examined and not all of the communication between the U.S. embassy diplomats and their Washington counterparts. Some of the more sensitive portions of those documents of which the White House did receive a copy remain classified and inaccessible. Equally important, the archival materials I investigated are communications between U.S. policy makers about their perceptions of events. This singular perspective has been reinforced by interviews and letters with some of those individuals involved in formulating and implementing U.S. policy during the 1964 crisis. I have had no opportunity to examine Brazilian primary sources, ${ }^{3}$ and this deficiency is only partly remedied by the use of secondary studies. Corroboration 
xiii Preface

of some of my findings has come from the incredibly generous offer of John W. F. Dulles to make available the notes from his many interviews with a number of Brazilians who were involved in the planning or the execution of the 1964 coup. These notes, which at the time were unpublished, enabled me to refine interpretations that would otherwise have been based on U.S. sources alone.

There are many others I would like to thank for their contributions to this work. I am grateful to the staff at the State Department for giving me access to files from the early sixties. I especially wish to thank Robert Ballantyne, who headed the Brazil Desk at the department, for his interest in my research.

I am grateful to Capt. Thomas V. Solan (U.S. Navy) and to Col. James Record (U.S. Air Force) for their assistance in reading military cables. In addition, Colonel Record was most helpful during all of my research as a liaison with Pentagon sources. I also wish to thank Debi Tucker for her assistance in locating research materials in the Washington, D.C., area.

I want to thank the staff at the Lyndon Baines Johnson Presidential Library in Austin, Texas, and particularly archivist Martin Elzy for his assistance in locating and declassifying documents. I also wish to thank the staff at the John F. Kennedy Presidential Library in Waltham, Massachusetts, especially archivist Megan Desnoyers for help in my use of documents there. There were other libraries that were valuable resources in the researching and writing of this book: The Lyndon B. Johnson School of Public Affairs Library and the Nettie Lee Benson Latin American Collection, both at the University of Texas at Austin, and the Library of Congress in Washington, D.C. I am grateful to the staff at each of these libraries for their assistance.

This book grew out of an independent research project at the Lyndon B. Johnson School of Public Affairs. I wish 


\section{xiv Preface}

to thank Henry David and Sidney Weintraub, members of the faculty, who were my advisors in the project. I appreciate their guidance and their ready encouragement and support.

In addition to archival materials and federal agency and congressional sources, this book draws heavily upon interviews with some important American figures who helped to shape this story. I am grateful to Vernon Walters, former defense attaché, for his valuable time and for the interesting stories he remembers from the period and to Thomas Mann, former assistant secretary of state for Latin American affairs for his time and interest in sharing his memory of events as well as his thoughts on the political theories behind the events. I am particularly indebted to former Ambassador Lincoln Gordon for his frank and detailed responses. In the interviews and in subsequent contacts, Dr. Gordon has been unfailingly generous toward me. I should note that, while these interviews provide important links in understanding the progression of events, the opinions and conclusions drawn from them and from the other research materials are mine and these gentlemen may disagree with my interpretations. It is a truism that hindsight should provide added clarity that might not have been available in the daily rush of living events. If this book is diminished because of any disagreements I might have with a policy judgement, the fault, once again, is mine and not theirs.

For reasons I regret, I am not at liberty to thank publicly one person whose help was substantial and valuable to me both personally and professionally. I am grateful nonetheless.

Finally, I wish to thank my family who have, in numerous ways, helped me in my research and writing. My special thanks goes to my husband, David Parker, who typed the manuscript and who has been a constant source of constructive criticism, support, and inspiration. 